\title{
The Efficacy of a Practical Activity in the Construction of Knowledge of the Concepts of Species and Phenotypic Plasticity Using the Boldo Mirim (Plectranthus neochilus Schltr.)
}

\author{
Neuza Rejane Wille Lima1, Gabriel Araujo Sodré2, Helena Roland Rodrigues Lima², \\ Sueli Soares de Sá Mancebo1, Luana Vieira Campos², Anna Gibson ${ }^{3}$, Victoria Souza ${ }^{3}$, \\ Wladimir Couto33, Lívia Di Giacomo33, Amanda Narcizo4, Adriana Quintela Lobão, \\ Cristina Maria Carvalho Delou1
}

\author{
${ }^{1}$ The Institute of Biology, Universidade Federal Fluminense (UFF), Rio De Janeiro, Brazil \\ ${ }^{2}$ ProPET Biofrontier of UFF, Rio De Janeiro, Brazil \\ ${ }^{3}$ The Discipline Teaching Activity of UFF, Rio De Janeiro, Brazil \\ ${ }^{4}$ Botany Discipline II of UFF, Rio De Janeiro, Brazil \\ Email: rejane_lima@id.uff.br
}

How to cite this paper: Lima, N. R. W, Sodre, G. A., Lima, H. R. R., Mancebo, S. S. de S., Campos, L. V., Gibson, A., Souza, V., Couto, W., Di Giacomo, L., Narciso, A., Lobão, A. Q., \& Delou, C. M. C. (2017). The Efficacy of a Practical Activity in the Construction of Knowledge of the Concepts of Species and Phenotypic Plasticity Using the Boldo Mirim (Plectranthus neochilus Schltr.). Creative Education, 8, 2036-2048.

https://doi.org/10.4236/ce.2017.813138

Received: August 22, 2017

Accepted: October 15, 2017

Published: October 18, 2017

Copyright $\odot 2017$ by authors and Scientific Research Publishing Inc. This work is licensed under the Creative Commons Attribution International License (CC BY 4.0).

http://creativecommons.org/licenses/by/4.0/

c) (i) Open Access

\begin{abstract}
The analyses efficacy of a practical activity addressing the measure of morphological characteristics of Boldo Mirim (Miniature Boldo), (Plectranthus neochilus Schltr.) which were cultivated in two conditions of solar intensity (50\% and 100\%), involved two professors and 7 students who participated at different ways in planning, performing and evaluating the results. This activity was carried out in 49 students matriculated in the discipline Botany II of 1st semester of the Biological Sciences course of UFF. The objective of the present study was to foment the construction of a significant learning about concept of specie and phenotypic plasticity. To perform the measurements on the leaves: 1) the foliar areas by two methods (weigh and counting); 2) the internode distance; and 3) the presence of trichome, two types of papers (baking and millimetric) and basic equipment such as manual calibration caliper $(\mathrm{mm})$, precision analytical balance $(0.001 \mathrm{~g})$ and a monocular stereoscope $(40 \times)$ were provided. It was verified that with the reduction in the availability of solar light, the Boldo Mirim increases its leaf area and the distance internodes for the best use of the luminosity in the photosynthetic process, whereas in conditions of full sunshine this plant invests less in leaf area and reduces the distance between leaves that are practically superimposed to avoid stress due to excess of light. After following the proposed protocol, the questionnaire with 12 questions about the plant's characteristics, the concepts of
\end{abstract}


species and of phenotypic plasticity, and the effectiveness of the practical activity were applied to the 14 groups of 3 to 4 students from the total of 49 ones. The correlation coefficients obtained from the comparison of the two methods used to measure the foliar area (weight and counting) was positive and significant for Branch type 1 (from plant raised at $100 \%$ of solar intensity: $r=0.806, \mathrm{n}=10 ; p \leq 0.005$ ) and for Branch type 2 (from plant raised at $50 \%$ of solar intensity: $r=0.755, \mathrm{n}=10 ; p \leq 0.005)$ as well. These results revealed that the proposal of the practice reached its goals. However, the critics of the 49 target students fell mainly on the restriction of the available time to the practical activity. In conclusion, the activity involvement revealed that the practical activity achieved its purpose. Thus, all the 56 students involved were able to construct the knowledge about the scientific methods, the concepts of species and phenotypic plasticity, and the therapeutic applicability of the Mirim Boldo, within a critical vision of the teaching-learning process.

\section{Keywords}

Plant Biometrics, Statistic, Questionnaire, Word Cloud

\section{Introduction}

The practical activity used in the teaching-learning process may involve simple or complex scientific experiments, depending on the age group and academic background of the target audience (Empinotti et al., 2014; Soares et al., 2015). When these activities are allied to the incentive in the development of the critical sense of the students, a greater effort can be generated among them in understanding and interpreting natural phenomena.

In plant biology teaching, a practical activity involving a basic analysis of the parts of a plant, such as comparative analysis of the leaf and its elements, can cover a range of questions involving knowledge ranging from the primary identification of the group until the understanding of its morphology, anatomy and physiology in relation to the luminous intensity and concentration of certain types of nutrients in the soil, to its ethnobotany importance in relation to the alimentary habits of different peoples and their possible therapeutic applications, among others (Weyers et al., 1998). Thus, from a single practice, one can foster the construction of students' knowledge about the importance of plants that are often overlooked by them in function of their interests by animals (Strgar, 2007), but which can be easily reverted when one addresses the innumerable relevance of flora to the flow of energy and environmental balance (Çil, 2016).

The present study outlined a practice to approach the concepts of species and phenotypic plasticity by gathering basic aspects about leaf external morphology (leaf area, texture, presence of trichome) and odor and the application of elementary statistical analyzes. In order to do so, a Boldo species was selected that is cultivated worldwide in both gardens and vegetable gardens of medicinal im- 
portance due to its aroma, inflorescence and chemical properties, Boldo Mirim Lima, 2017; Lima et al., 2017).

The Mirim Boldo, scientifically called Plectranthus neochilus and described by Rudolf Schlecthter in 1896, is a plant of the family Lamiaceae originating in Africa, introduced in Brazil during the colonial period and also cultivated in countries of Europe and Asia.

The target species of the present study is also known as Japanese Boldo and presents expressive aromatic and ornamental characteristics and medicinal importance, being popularly used in the treatment of hepatic insufficiency and dyspepsia, replacing the species Peumus boldus Molina, The Boldo from Chile or True Boldo (Rosal, 2008; Rosal et al., 2011; Viana, 2011).

The Boldo Mirim also expresses variations regarding external morphology, internal leaf anatomy and chemical characteristics (yield of essential oils) as a function of variations in the light spectrum and nutrient concentration of the soil (Rosal et al., 2011; Viana, 2011). These variations characterize a phenotypic plasticity that is perceptible to sight, smell and touch, being easily measurable by simple methods such as counting the number of leaves, spacing of the leaves along the branch (distance internodes), thickness and roughness, The leaf area, color and odor (Rosal et al., 2011, Viana, 2011, Lima, 2017; Lima et al., 2017). Thus, the phenotypic plasticity of the leaves has great didactic potential to be explored through practical activities to discuss the concept of phenotypic plasticity (Lima et al., 2017).

The objective of the present study was to perform and analyze the effectiveness of a practical activity in the programmatic content of the Botany II course that is regularly offered to students of the first period of the Biological Sciences course. The practice involved the biometry of the Boldo Mirim leaves, and questionnaire application to discuss the concept and species from the demonstration of the phenotypic plasticity of this plant in response to two conditions of insolation.

\section{Material and Methods}

The different stages for conducting and analyzing the practical activity involved the participation of two PET scholarship recipients (MEC-SESu, named as petianos) linked to ProPET Biofrontier, students of Biological Sciences degree from the Institute of Biology of the Federal Fluminense University. They acted in the planning and realization of the practical activities, elaboration and application of the questionnaire, accomplishment analysis and interpretation of the results. In addition, the practical activity was also attended by five students who help the professor responsible for the discipline in question.

The practical activity was applied in the Botany Sector of the Biology Institute of the Fluminense Federal University (UFF) in the afternoon period of March 29, 2017 for a group of students who were enrolled in the discipline Botany II.

Before the practical activity, all the students attended the theoretical lesson of 
90 minutes during the morning period. In this activity, the responsible teacher addressed contents related to the Concepts of Species and the characteristics that can be used to differentiate the taxonomic groups.

In the evening period, the forty-nine students who attended the practical activity were randomly distributed in three sub-groups (A, B, C), forming 14 team of 3 to 4 students. These sub-groups were attended three hours of practical activity with 90 minutes of duration each.

For each of the 14 team of students a tray containing two branches of Boldo Mirim that grew in different conditions of sunshine was delivered. The Branch type 1 was cultivated under conditions of full sunshine. The branch type 2 was cultivated under $50 \%$ insolation inside the greenhouse (Figure 1).
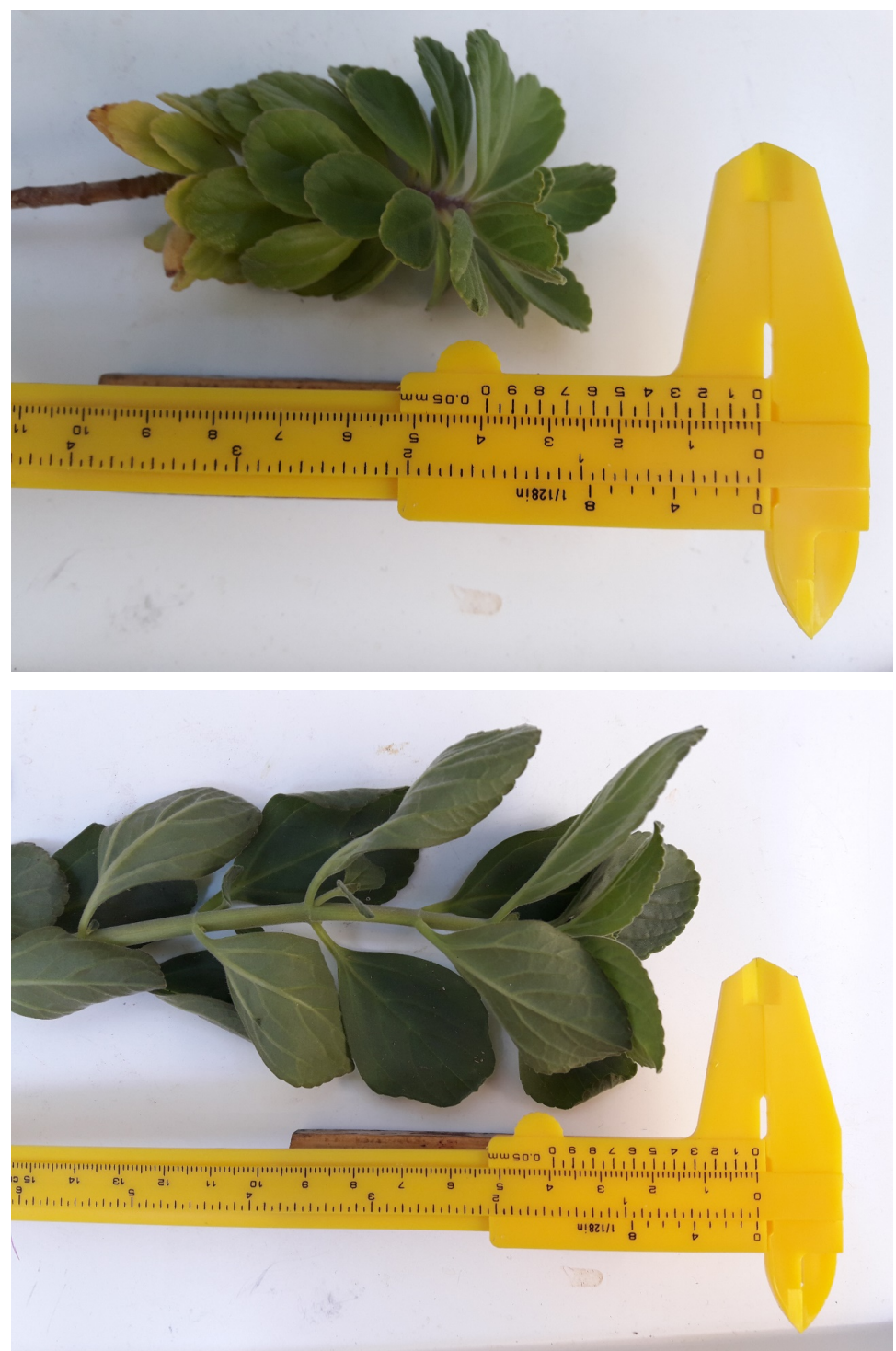

Figure 1. Branches of Boldo Mirim (Plectranthus neochilus Schltr.) from plant that was cultivated under $100 \%$ insolation (above) and 12 Branches type 2 that was cultivated under $50 \%$ insolation (below), having a plastic pachymeter with $20 \mathrm{~cm}$ in length as a reference. 
After the delivery of the brunches, students had to collectively responded if they could belong to the same species and if they knew and what plants they were. After the answers obtained, a folder containing the following materials was delivered to each group: (a) 2 records for recording the results; (b) 2 sheets of millimeter paper; (c) 2 sheets of banking paper; (d) 1 pencil with rubber; (e) 1 sharpener; (f) 1 plastic marker pen; (g) 1 plastic pachymeter with $20 \mathrm{~cm}$ long; (h) 3 scissors; (i) 2 plastic bags; and (j) questionnaire with 12 questions.

After delivery of these materials, it was explained what would be measured in practice (Table 1) and a free consent term was given for each student to complete and sign and report age and gender data.

All statistical analyzes of the data were performed including all the results obtained (a priori test) or excluding discrepant data (a posteriori test) through the statistical program Excel 2010. The Coefficient of Variation of Person (CV) and the Peason Correlation ( $r$ ) were calculated.

It was applied a questionnaire with 12 questions previously elaborated (Table 2) by the professors and student involved in the planning of practical activities in order to evaluate the perception of the 49 students about Boldo Mirim and the activities proposed. The answers obtained were analyzed through the Cloud Word technique through the website https://wordart.com/.

Fifteen days later, the results of practical activity explained to the students

Table 1. Steps carried out by students delivered practical activity with Boldo Mirim.

\section{Activities}

1. The apical distance of Branch type 1 was measured from the tip of the branch to the last leaf (Figure 1). The section of $15 \mathrm{~cm}$ from the tip of Branches type 2 was considered since its total apical distance was greater than $50 \mathrm{~cm}$, involving a lot material.

2. The leaves from each branch were removed from stems to measure the internodal distance (distance between the position of the leaves on each steam).

3. To observe the leaves and their structures (veins and trichomes) monocular stereoscope (40X).

4. The outline of all the leaves of each branch was drawn with pencil on paper millimeter and baking paper was well.

5. To count the number of squares of $1 \mathrm{~mm}$ occupied by the leaves draw of each branch

6. To cut out the leaves that were drawn on the banking paper, put in the plastic bags identified with the marker pen.

7. To weight a square of $5 \mathrm{~cm} \times 5 \mathrm{~cm}\left(25 \mathrm{~cm}^{2}\right)$ of banking paper to calculate the leaf area of each branch through the rule of three

(the method of finding the fourth term in a proportion when three terms are given), using a precision balance $(0.01 \mathrm{~g})$.

8. To weigh each group of leaves belonging to each branch, using a precision balance $(0.01 \mathrm{~g})$.

9. To answer only the no. 3 and 6 listed in Table 2 after the practical activity.

10. To perform extra activities at home to answer the others 10 questions $(1-2,4-5,7-12)$ listed in Table 2. 
Table 2. Questions applied to students after practical activity.

\begin{tabular}{|c|}
\hline Questions \\
\hline 1. What were the major differences of leaves from Branches 1 and 2 ? \\
\hline 2. What were the smallest differences noted on leaves from Branches 1 and 2 ? \\
\hline $\begin{array}{l}\text { 3. Based on the activity performed in the practical activity can you say that Branch } 1 \text { and } 2 \text { belong to } \\
\text { the same taxonomic group? Why? }\end{array}$ \\
\hline 4. Can we call these taxonomic groups as species? Why? \\
\hline 5. Taking into account your answer in item 3 and 4 , what is species? \\
\hline 6. What is phenotypic plasticity? \\
\hline 7. Did you know Boldo before practical activities? \\
\hline 8. Do you know any other kind of Boldo? Which ones are they? \\
\hline 9. Do you know what herbal properties are? \\
\hline 10. What are the positive points of practice? \\
\hline 11. What are the negative points of practice? \\
\hline 12. Do you have suggestions to improve this practical activity? Which ones are they? \\
\hline
\end{tabular}

about the results obtained so that they knew about the knowledge that was generated from the biometric analyzes of branches and about the perceptions they built on Boldo Mirim and other species of the plants popularly named as Boldo.

\section{Results}

A total of 49 students participated in the practical activity, among them 14 were male and 35 female. The majority of them were between 18 and 19 years old (67\%) and the remainder were between 20 and 23 years old (33\%), representing a heterogeneous group with respect to gender but homogeneous as regards the age group. Only one student was not in the first period of Biological course.

After the questions applied collectively, some students responded that the target plant of the practical activity was the Boldo because of the odor it exuded.

All 14 groups of students were oriented to analyze the leaf area of each branch type by two methods (weight and counting) and to respond the questionnaire. However two of these 14 groups did not deliver the results of the leaf area by the second method or handed over the answer of the questionnaire.

The Branches type 1 involved a total of 518 leaves, with an average of 37.0 per each of them. The Branches type 2 had a total of 303 leaves analyzed and the average was 21.6 per each of them (Table 3). This result showed that the number of leaves was 1.7 higher in Branch 1 in relation to Branch 2, and the number of leaves was directly related to the degree of solar intensity.

The coefficient of variation of Person showed that the variability of the data in relation to the average was about two times greater for the Branch 2 in relation to the Branch 1 (Table 3).

All these results together (Table 3 ) indicated that the shading condition caused a smaller number of leaves per branch, but a greater diversification in the 
Table 3. Analyze statistics of the arithmetic measurements of leaves of the 12 Branches type 1 (cultivated under $100 \%$ insolation) and 12 Branches type 2 (cultivated under 50\% insolation) of Boldo Mirim, the standard deviation (SD) and Person's coefficient of variation $\mathrm{CV}$ ).

\begin{tabular}{ccccc}
\hline Branches & Qty. of leaves & Average & SD & CV \\
\hline 1 & 518 & 37.0 & 6.41 & 17.32 \\
2 & 303 & 21.6 & 7.69 & 35.54 \\
\hline
\end{tabular}

number of leaves per branch in relation to the branches of the plants that grew in the condition of full sunshine.

The results of the apical distances of Branch 1 varied between $2.2 \mathrm{~cm}$ and 5.5 $\mathrm{cm}$ and were, on average, $3.8 \mathrm{~cm}$. Stretch of the stems below did not present any leaf, being a pattern observed throughout the crop.

As Branch 2 presented leaves along the whole stem and in all the plants of the crop, it was defined that the students considered only $15 \mathrm{~cm}$ of apical distance and determined the characteristics of the leaves and their distances internodes beginning with the first leaf above the determined section.

The distances internodes for Branch 1 varied between $0.11 \mathrm{~cm}$ and $0.39 \mathrm{~cm}$ and presented an average of $0.19 \mathrm{~cm}$. For Branch 2, the median distance of the internodes was $2.21 \mathrm{~cm}$ with a variation between $1.17 \mathrm{~cm}$ and $3.02 \mathrm{~cm}$. Thus, on average the distance between nodes in Branch 2 was about 12 times greater than in Branch 1 . These results indicate that with a higher solar incidence a reduction in internodes distances occurs.

It was verified that with the reduction in the availability of solar light, the Boldo Mirim increases its leaf area and the distance internodes for the best use of the luminosity in the photosynthetic process, whereas in conditions of full sunshine this plant invests less in leaf area and reduces the distance between leaves that are practically superimposed to avoid stress due to excess of light.

Comparatively, the results of the foliar areas determined by the counting method were similar to the results generated by the weighing method for most groups of students except for groups 6a and 2c (Figure 2).

The Pearson correlation $(r)$ between the foliar areas obtained by the two methods indicated that there was a positive relation for the results of each branch (Table 4). However, in the case of Branch 1, the results group 6a and mainly group $2 c$ presented different results. The same happened between the results and of foliar areas for the Branche2 (Figure 2).

The Pearson correlation $(r)$ between the foliar areas obtained by the two methods (weight and counting) indicated that there was a positive relation for the results of each branch (Table 4). However, in the case of Branch 1, the results group 6a and mainly group $2 \mathrm{c}$ presented different results. The same happened between the results and of foliar areas for the Bouquet 2 (Figure 2).

The correlation coefficient for the results of the foliar areas obtained by the two methods was not significant $(p>0.05)$ when all values of the 12 groups of 
Table 4. Correlation analysis $(r)$ between leaf area obtained by weight method and counting method (Figure 2), involving all results obtained (a priori test; $\mathrm{n}=12$ ) and leaf area excluding the discrepant results (a posteriori; $\mathrm{n}=11$ or $\mathrm{n}=10$ ).

\begin{tabular}{cccc}
\hline Branches & $($ n) & $\boldsymbol{r}$ & $\boldsymbol{p}$ \\
\hline 1 & 12 & 0.696 & $>0.05$ \\
& 11 & 0.806 & $\leq 0.05$ \\
2 & 12 & 0.510 & $>0.05$ \\
& 10 & 0.755 & $\leq 0.05$ \\
\hline
\end{tabular}

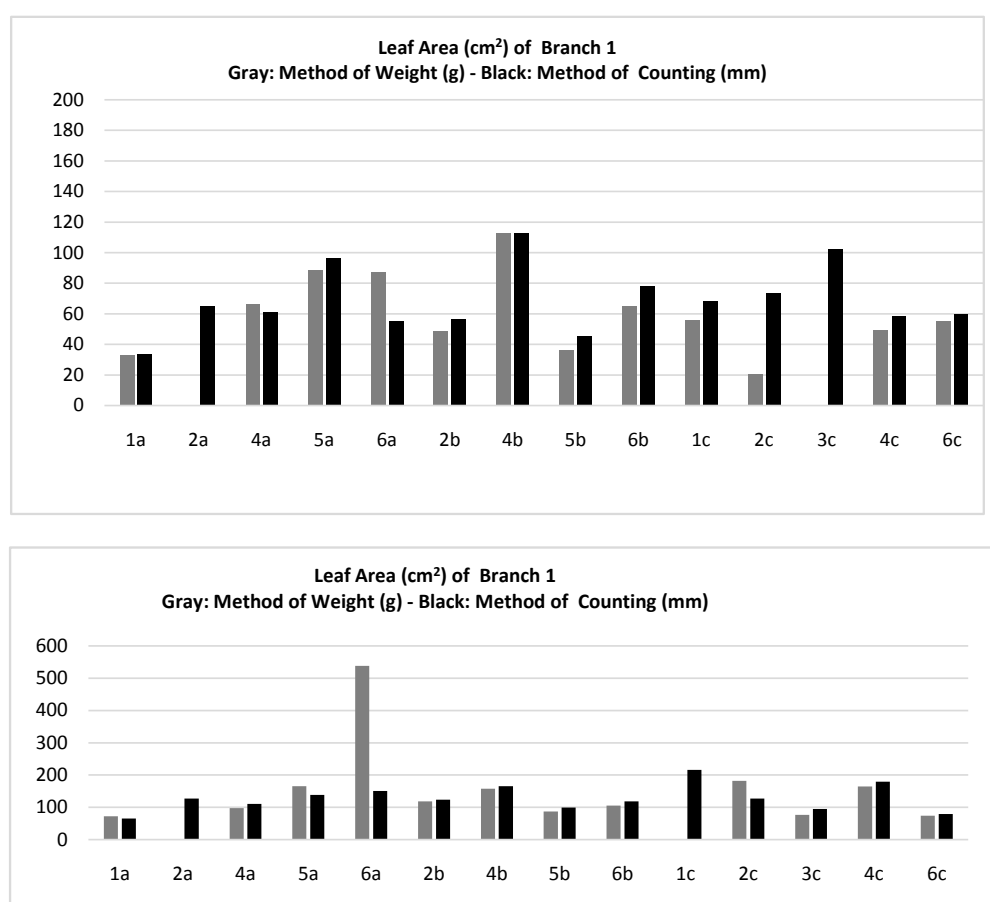

Figure 2. Results of the foliar areas $\left(\mathrm{cm}^{2}\right)$ of Branches 1 (above) and Branch 2 (below) that are generated by the 14 groups of students $(1 \mathrm{a}-6 \mathrm{c})$ obtained by the two methods (weight and counting).

students were included (a priori test) (Table 2). However, when the discrepant results generated by these groups for Branch 1 were excluded from the analysis (a posteriori test), the correlation coefficient became significant $(p \leq 0.05)$.

Group 6a underestimated the leaf area of both Branch 1 and Branch 2 when using the counting method through drawing on graph paper because it considered that $50 \mathrm{~mm}^{2}$ frame had $10 \mathrm{~mm}^{2}$. Group $2 \mathrm{c}$ overestimated the leaf area of the only branch 1 when using the counting method for the inverse motif, that is, considering the $10 \mathrm{~mm}^{2}$ frame to be $50 \mathrm{~mm}^{2}$ (Figure 1).

The analysis of Word Clouds applied to analyze the answers obtained from the 12 questions applied after the practical activity revealed through the size of the words which were those most used by the students (Figure 3 and Figure 4).

For example, question number 1 indicated that leaf size was the most cited feature, followed by distance internodes, leaf color (yellow for leaves of Branch 


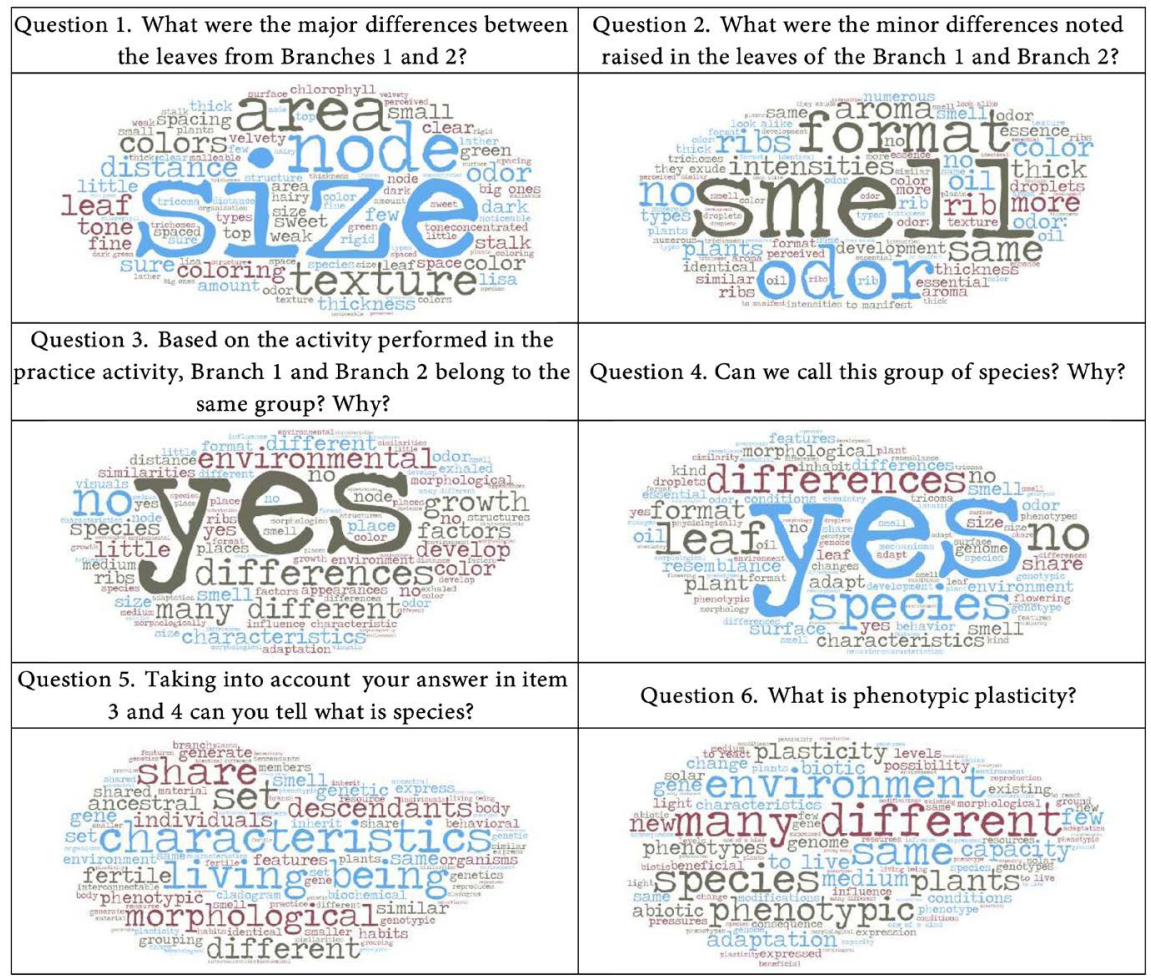

Figure 3. Cloud Word analyses of the answer of the 49 students to the questionnaire (questions from 1 to 6, Table 2) applied after the practical activities.

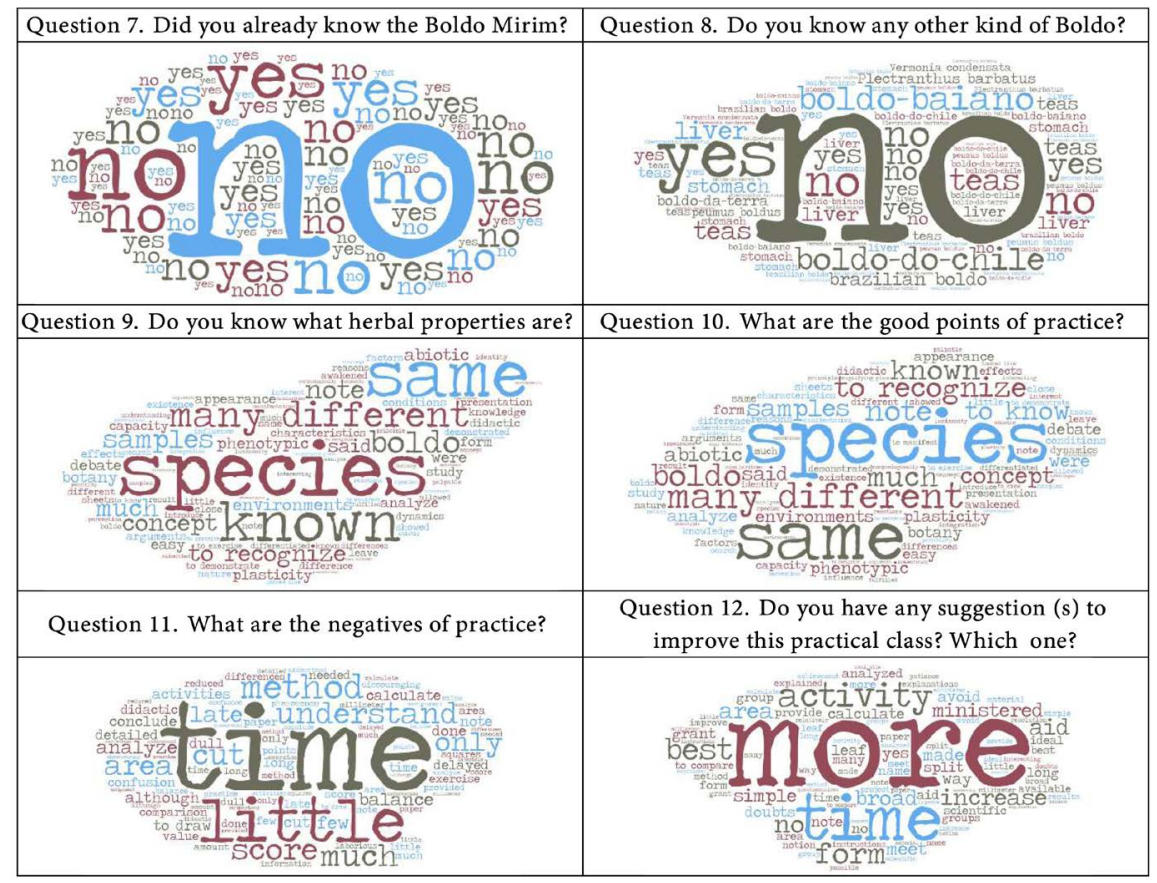

Figure 4. Cloud Word analyses of the answer of the 49 students to the questionnaire (questions from 1 to 6, Table 2) applied after the practical activities.

1), leaf texture (thicker for the leaves of Branch 1), leaf area, leaf thickness and the presence of a greater quantity of trichomes in leaves of Branch 1, and the 
odor (Figure 1 and Figure 3). On the other hand, when asked for the smaller differences between the leaves of the two types of Branches, the most frequent responses were: odor, vein, leaf shape, leaf thickness, leaf color, quantity of trichome and texture (Figure 3).

The affirmative answers and justifications for questions 3 to 6 revealed that most of students appropriated the concepts of species and phenotypic plasticity (Figure 3). The responses in Figure 3 revealed that most of the students were unaware of Boldo Mirim and the other species also known as Boldo. But those who knew the Boldo used the words liver, tea, combat, pain, benefit to explain the importance of this plant.

Finally, for the questions about the efficacy of the practice the students reported that there would be a need for more time and part reported that this activity involved many techniques since the pachymeter was used to measure distances apical and internodes, the stereoscope to observe the veins of the leaves and their trichomes and the digital scale to weigh the drawings obtained to measure the leaf area (Figure 4).

Some students show concern about using the equipment available to make the measurements during the practical activity because they felt lack of previous specific training. However, at the end of the activity everyone felt comfortable in handling the equipment.

\section{Discussion}

In Brazil, the plants popularly known as Boldo involve several species of different genera and family: Peumus (Monimiaceae), Vernimia (Asteracea) and Plectranthus (Lamiaceae). The first is from Chile, being the most commercialized for tea production. The other two are from different parts of Africa, Asia, and Europe. All of them have been used to treat digestive and hepatic dysfunctions (Brandolt et al., 2007; Rosal, 2008; Viana et al., 2010; Rosal et al., 2011; Waldia et al., 2011; Pontes et al., 2012; Lima, 2017; Lima et al., 2017). Therefore, those species may be approached by different point of view.

These species are the subject of disciplines such as ethnobotany and pharmacognosis ranging from the history of their cultivation, collection, conservation, commercialization (Silva et al., 2010; Viu et al., 2010; Coradin et al., 2011) to the extraction and identification and dosage of substances with active principles such as essential oils and components such as boldine which may be a novel compound for the development of anticancer strategies and phenolic compounds with anti-oxidant properties (Ascensão, 1998; Rosal, 2008; Gerhardt et al., 2009; Menon et al., 2012).

It should be noted that the phenotypic plasticity of some plants such as Boldo Mirim can also make it difficult to identify the right species for phytotherapeutic use species. However, wrong therapeutic use of plant must be avoided (Lima et al., 2017). For example, tea or juice consumption of certain medicinal plants that are recognized as effective in phytotherapy can, when ingested in high doses, 
cause abdominal discomfort and even abortion and edemas in the liver and kidneys. This is the case of the species Plectranthus barbatus (Andres) and which despite its recognized therapeutic importance should be consumed without exaggeration (Brandolt et al., 2007). This plant is also native to Africa and is called Brazilian Boldo, and is sometimes confused with one of its relatives, the Boldo Mirim (Lima et al., 2017).

The phenotypic plasticity of Boldo Mirim in morphological and physiological terms is easily observable (Rosal, 2008; Rosal et al., 2011; Lima, 2017; Lima et al., 2017) and as in the present study it can be approached at different levels from elementary school to university education to different purposes involving biology, elementary mathematics (counting and comparative measures), exploratory statistics (graphic, coefficient of variation and test of correlation), and the use of basic equipment such as the pachymeter, the monocular stereoscope, and digital scale Lima, 2017; Lima et al., 2017). In addition, the parametric and non-parametric analysis of variance of the data can be applied in others practical activities context, involving students of Biology, to explore the large variation of biometric data of Boldo Mirim raised in gardens at different environmental conditions Lima, 2017; Lima et al., 2017).

Mathematics and Statistics (Stodolsky, 1985) and also the use of some scientific equipment may cause aversion to the part of the students, in particular the digital balance (present study). However, it can be demystified by demonstrating their importance of them to understand the nature of living beings as explained by the end of practical activity and during the theoretical lesson fifteen days after the practical activity was applied.

The present study demonstrated to all the fifty six involved students (two petianos, five students who help the professor responsible for the discipline in question, and the 49 students of the discipline Botany II) how mathematics, statistic and biology can be interconnected to discuss about concepts of specie and the phenotypic plasticity.

Moreover, the planning of the practical activity as well as its analysis and interpretation is an integral part of the formation of the petianos that must involve in teaching, research and extension activities in an inseparable way and, academic education through extracurricular and interdisciplinary activities (Castro et al., 2014). In addition, it was possible to approach the phytotherapic use of the plant (Lorenzi \& Matos, 2002; Silva et al., 2010; Lopes et al., 2011) in order to answer the phytotherapeutic importance of the Boldo species. This context led the students to research on the subject to answer to the questionnaire carried at home.

Based on all the results, we concluded that the practical activities associated to the questionnaires were relevant to the academic education of students and the construction of knowledge about the importance of plants. Moreover, they could develop a critical vision of the teaching-learning process, fulfilling the purposes of the present study. 


\section{References}

Ascensão, L., Figueiredo, A. C., Barroso, J. G., Pedro, L. G., Schripsema, J., Deans, S. G., \& Scheffer, J. J. C. (1998). Plectranthus madagascariensis: Morphology of the Glandular Trichomes, Essential Oil Composition, and Its Biological Activity. Journal of Plant Sciences, 159, 31-38. https://doi.org/10.1086/297518

Brandolt, T. D., Rodrigues, C. C., Ferrão, S. M. N., \& Silva, G. M. B. (2007). Efeito do extrato de Plectranthus barbatus (Andr.) Benth no desempenho reprodutivo de Rattus novergicus (Berkenhout, 1769). [Effect of the Extract of Plectranthus barbatus (Andr.) Benth on the reproductive performance of Rattus novergicus.] Biotemas, 20, 49-58.

Castro, H. C., Lima, N. R. W., Santos, C. S. G., Carlos, H. C., Mendes, A. B., Silva, G., Braga, G. L., Freitas, G., Feistel, M. A., Teixeira, P., \& Santos, R. (2014). BioFronteiras-UFF: Exploring an Educational Program that Spreads the Science Frontiers Themes. International Journal of Educational Management, 1, 1-5.

Çil, E. (2016). Instructional Integration of Disciplines for Promoting Children's Positive Attitudes towards Plants. Journal of Biological Education, 50, 366-383. https://doi.org/10.1080/00219266.2015.1117512

Coradin, L., Siminski, A., \& Reis, A. (2011). Espécies nativas da flora brasileira de valor econômico atual ou potencial plantas para o future-Região Sul (5p). [Native Species of Brazilian Flora of Current Economic Value or Potential Plants for the Future-Southern Region.] Ministério do Meio Ambiente-MMA.

Empinotti, A., Barth, A., Niedzielski, D., Tusset, E. A., Stachniak, E., \& Krupek, R. A. (2014). Botânica em prática: atividades práticas e experimentos para o ensino fundamental. [Botany in Practice: Practical Activities and Experiments for Elementary Education.] Revista Ensino \& Pesquisa, 12, 52-103.

Gerhardt, D., Horn, A. P., Gaelzer, M. M., Frozza, R. L., Delgado-Cañedo, A., Pelegrini, A. L., Henriques, A. T., Lenz, G., \& Salbego, C. (2009). Boldine: A Potential New Antiproliferative Drug against Glioma Cell Lines. Investigation New Drugs, 27, 517-525. https://doi.org/10.1007/s10637-008-9203-7

Lima, N. R. W. (2017). Boldo Mirim em diferentes ambientes: práticas educacionais, estímulos sensoriais e construção do conhecimento. [Boldo Mirim in Different Environments: Educational Practices, Sensorial Stimuli and Knowledge Construction.] Niterói, RJ: ABDIn/PERSE.

Lima, N. R. W. L., Sodré, G. A., Lima, H. R. R., Paiva, S. R., Lobão, A. Q., \& Coutinho, A. J. (2017). Plasticidade fenotípica. [Phenotypicplasticity.] Revista de Ciência Elementar, 5, 1-7. https://doi.org/10.24927/rce2017.017

Lopes, I. S., Guido, L. F. E., Cunha, A. M. O., \& Jacobucci, D. F. C. (2011). Oficina de plantas medicinais e do cerrado como intercâmbio entre a pesquisa acadêmica e a prática docente no espaço escolar. [Workshop of Medicinal Plants and the Cerrado as an Interchange between Academic Research and Teaching Practice in School.] Ensino, Saúde e Ambiente, 4, 34-48.

Lorenzi, H., \& Matos, F. J. A. (2002). Plantas medicinais no Brasil-Nativas e exóticas (512 p.). Nova Odessa: Plantarum.

Menon, D. B., Sasikumar, J. M., \& Latha, K. (2012). Phytochemical Analysis and Antioxidant Activity of Methanolic Extract of Plectranthushadiensis (Forssk.) Schweinf. exSpreng. Aerial Parts. Indian Journal of Natural Products and Resources, 3, 359-365.

Pontes, S. M., Souza, A. P. M., Barreto, B. F., Oliveira, H. S. B., Oliveira, L. B. P., Alynne Mendonça Saraiva, A. M., Costa, D. A., \& Carmo, E. S. (2012). Utilização de plantas medicinais potencialmente nocivas durante a gestação na cidade de Cuité-PB. [Use of 
Potentially Harmful Medicinal Plants during Pregnancy in the City of Cuité-PB.] Comunicação em ciêNcias da Saúde, 23, 305-311.

Rosal, L. F. (2008). Produção de biomassa, óleo essencial e características fisiológicas e anatômicas foliares de Plectranthus neochilus Schlechter em função da adubação orgânica, malhas coloridas e idade das plantas (134 p.). [Production of Biomass, Essential Oil and Foliar Physiological and Anatomical Characteristics of Plectranthus neochilus Schlechter Due to Organic Fertilization, Color Meshes and Plant Age.J Tese de Doutorado, Lavras: Universidade Federalde Lavras.

Rosal, L. F., Pinto, J. E. B., Bertolucci, S. K. V., Brant, R. S., Nicolau, E. S., \& Péricles Barreto Alves, P. B. (2011). Produção vegetal e de óleo essencial de boldo pequeno em função de fontes de adubos orgânicos. [Vegetable Production and Small Boldo Essential Oil Due to Sources of Organic Fertilizers.] Revista Ceres, 58, 670-678. https://doi.org/10.1590/S0034-737X2011000500020

Silva, A. C., Fortes, M. E. R., Bastos, A. S., Linhares, J. F. P., \& Rodrigues, M. I. A. (2010). $\mathrm{O}$ valor do consenso de uso das espécies vegetais encontradas nos quintais da comunidade rural de Igaraú, São Luis, MA. [The Value of the Consensus of Use of the Vegetal Species Found in the Yards of the Rural Community of Igaraú, São Luis, MA.] Pesquisa em Foco, 18, 47-58.

Soares, R. M., \& Baiotto, C. R. (2015). Aulas práticas de biologia: suas aplicações e o contraponto desta prática. [Practical Classes of Biology: Its Applications and the Counterpoint of This Practice.] Revista Dialogus, 4, 53-68.

Stodolsky, S. S. (1985). Telling Math: Origins of Math Aversion and Anxiety. Educational Psychologist, 20, 125-133.

Strgar, J. (2007). Increasing the Interest of Students in Plants. Journal of Biological Education, 42, 19-23. https://doi.org/10.1080/00219266.2007.9656102

Viana, A. J. S. (2011). Estudo químico e de atividade biológica DE Plectranthus neochilus Schltr. (Lamiaceae) (128 p.). [Chemical and Biological Activity Study DE Plectranthus neochilus Schltr. (Lamiaceae).J Dissertação de Mestrado, Diamantina: Universidade Federal dos Vales do Jequitinhonha e Mucuri.

Viu, A. F. M., Viu, M. A. O., \& Campos, L. Z. O. (2010). Etnobotânica: Uma questão de gênero? Etnobotany: A Gender Question? [Ethnobotany: A Question of Gender? Etnobotany: A Gender Question?] Revista Brasileira de Agroecologia, 5, 138-147.

Waldia, S., Joshia, B., Pathaka, C. U., \& Joshi, M. C. (2011). The Genus Plectranthus in India and Its Chemistry. Chemistry \& Biodiversity, 8, 244-252. https://doi.org/10.1002/cbdv.201000048

Weyers, J. D. B., Höglund, H.-O., \& McEwen, B. (1998). Teaching Botany on the Sunny Side of the Tree: Promoting Investigative Studies of Plant Ecophysiology through Observations and Experiments on Sun and Shade Leaves. Journal of Biological, 32, 181-190. 